Note

|||||||||||||||||||||||||||||||||||||||||||

\title{
Combination of Sulfur Isotope Ratio of Non-sea Salt Sulfate and Lead-210 Concentration in Aerosols as an Index of Long-range Transported Aerosols
}

\author{
Takashi Kotani ${ }^{* * *}$, Fumitaka YanAGISAWA ${ }^{* *}$, Yutaka KAnAI****, \\ Akiko MryaoKA***** and Naofumi AKATA****** \\ *Tsuruoka National College of Technology \\ 104 Sawada, Inooka, Tsuruoka-shi, Yamagata Pref. 997-0842, Japan \\ **Graduate School of Science and Engineering, Yamagata University \\ $* * *$ Faculty of Science, Yamagata University \\ 1-4-12 Kojirakawa, Yamagata-shi, Yamagata Pref. 990-8560, Japan \\ $* * *$ Geological Survey of Japan, AIST \\ AIST Tsukuba Central 7, 1-1-1 Higashi, Tsukuba-shi, Ibaraki Pref. 305-8567, Japan \\ *****Mitsubishi Material Techno Co. \\ 1-297 Kitabukuro, Ohmiya-ku, Saitama-shi, Saitama Pref. 330-0835, Japan \\ $* * * * *$ Institute for Environmental Sciences \\ 1-7 Ienomae, Obuchi, Rokkasho-mura, Aomori Pref. 039-3212, Japan
}

Received July 11, 2011

\begin{abstract}
We studied on the validity of combination of ${ }^{210} \mathrm{~Pb}$ concentration and sulfur isotope ratio of non-sea salt sulfate in aerosols as an index of long-range transported aerosols. As a result, it was found that multi-isotope method using ${ }^{210} \mathrm{~Pb}$ and $\delta^{34} \mathrm{~S}$ was useful for long-range transported aerosols from the Asian continent.
\end{abstract}

Key Words : sulfur isotope ratio, lead-210, aerosol, Asian dust

\section{Introduction}

In the Asian dust (Kosa) events, continental surface soil particles (from the arid and/or semiarid region in China and Mongolia) are blown into the upper atmosphere and transported aloft by strong westerly winds; the dust is often observed over Japan in spring and fall seasons. Asian dust has been attracting attention in many fields because of its significant influences on both the local and global environments ${ }^{1)}$. In addition, various pollutants are also brought from the Asian continent to Japanese Archipelago ${ }^{2)}$ as gaseous materials and/or submicron aerosols to which they attach. Many re- searchers have studied on characteristics and influence of long-range transported chemical substances ${ }^{2)-5}$. Therefore, it is important to understand the source and properties of Asian dust aerosols.

Radioisotopes (for example : ${ }^{210} \mathrm{~Pb}$ and ${ }^{137} \mathrm{Cs}$ ) and isotope ratios (for example : $\delta^{34} \mathrm{~S},{ }^{207} \mathrm{~Pb} /{ }^{206} \mathrm{~Pb}$ and ${ }^{87} \mathrm{Sr} /{ }^{86} \mathrm{Sr}$ ) are often used as tracers for evaluating the source of aerosols ${ }^{6)-9}$. Lead-210 $\left.{ }^{210} \mathrm{~Pb}\right)$ is a natural radionuclide in the ${ }^{238} \mathrm{U}$ decay series with relatively long half-life $\left(\mathrm{T}_{1 / 2}\right.$ of $22.3 \mathrm{y})$. Airborne ${ }^{210} \mathrm{~Pb}$ is produced from its precursor, ${ }^{222} \mathrm{Rn}\left(\mathrm{T}_{1 / 2}\right.$ of $\left.3.82 \mathrm{~d}\right)$, emanated from the ground surface. The ${ }^{210} \mathrm{~Pb}$ attaches to aerosol particles near the ground surface, and is trans- 
ported through the atmosphere ${ }^{10)}$. On the other hands, it is well-known that the atmospheric sulfur has natural and anthropogenic origins. The source of anthropogenic sulfur is mainly fossil fuel combustion. Recently, Chinese economic development is remarkable, and the emission rate of the anthropogenic sulfur is increasing. The anthropogenic sulfur has been carried as Asian dust particles (gypsum and attached particles). Therefore, in Japan, it is suggested that source of sulfur and ${ }^{210} \mathrm{~Pb}$ are East Asian Region in fall to spring ${ }^{9), 11}$.

We have observed atmospheric aerosols in Tsuruoka City, Yamagata Prefecture since 1993, and reported the chemical composition ${ }^{12}$. In addition, we also reported sulfur isotope ratio of non-sea salt sulfate ${ }_{\text {nss }} \delta^{34} \mathrm{~S}$ ) and ${ }^{210} \mathrm{~Pb}$ in aerosols in the same period ${ }^{13), 14)}$ to clarify the characteristics of long-range transported aerosol particles. However, the relationship between ${ }_{n s s} \delta^{34} \mathrm{~S}$ and ${ }^{210} \mathrm{~Pb}$ in aerosols has not yet been studied. If ${ }_{\text {nss }} \delta^{34} \mathrm{~S}$ and ${ }^{210} \mathrm{~Pb}$ show a good correlation, their combination may be considered as a reliable indicator. In this paper, we reported the relationship between $\delta^{34} \mathrm{~S}$ of sulfate and ${ }^{210} \mathrm{~Pb}$ in aerosols to evaluate them as an indicator of long-range transported aerosols from East Asian continent (Asian dust and pollutants).

\section{Experimental}

The sampling method is identical to that we used previously ${ }^{13)}$. The analytical procedures and results of $\delta^{34} \mathrm{~S},{ }^{210} \mathrm{~Pb}$ and major chemical components has also been reported elsewhere ${ }^{13), 14}$. Briefly speaking, the sampling site is the building top of Tsuruoka National College of Engineering Technology in Tsuruoka, Yamagata Prefecture, Japan $\left(38^{\circ} 42^{\prime} \mathrm{N}, 139^{\circ} 47^{\prime}\right.$ E, approximately $9 \mathrm{~km}$ away from the seashore

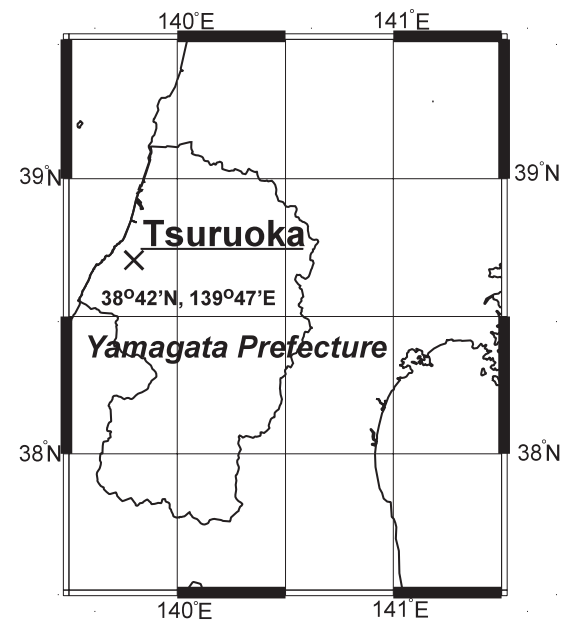

Fig. 1 Location map of sampling site (Tsuruoka City)

of the Sea of Japan and $20 \mathrm{~m}$ high above the ground level), shown in Fig. 1. The aerosol samples were collected for about 5 days using a high-volume air sampler (HVC-1000, Shibata) with a quartz-fiber filter $(20.3 \mathrm{~cm} \times 25.4 \mathrm{~cm}$, QR-100, Advantec) and/or PTFE filter (PF040, Advantec, Japan) during 1996 to 1999. The airflow rate was approximately $700 \mathrm{~L} \mathrm{~min}^{-1}$.

The filters with collected aerosols were cut into quarters and the extraction with water was carried out by ultrasonic-wave. After filtration, $\mathrm{Na}^{+}$and $\mathrm{SO}_{4}{ }^{2-}$ concentrations were measured by ICP-AES (SPS7000A, Seiko) and Ion chromatography (2020i, Dionex), respectively. After chemical analysis, $\mathrm{SO}_{4}{ }^{2-}$ was precipitated as $\mathrm{BaSO}_{4}$ from the extracted solution for $\delta^{34} \mathrm{~S}$ analysis. For the $\delta^{34} \mathrm{~S}$ analysis, the $\mathrm{BaSO}_{4}$ precipitate was dried and converted to $\mathrm{SO}_{2}$ through thermal decomposition using a mixture of $\mathrm{SiO}_{2}-\mathrm{V}_{2} \mathrm{O}_{5}$ in a vacuum line ${ }^{15)}$. Subsequently, $\delta^{34} \mathrm{~S}$ was measured using a stable isotope ratio mass spectrometer (Delta-E, FiniganMAT). The results of $\delta^{34} \mathrm{~S}$ is reported in Canyon Diablo Troilite (CDT) scale, which is de- 

in aerosols as an index of long-range transported aerosols

fined as

$$
\delta^{34} \mathrm{~S}=\left(\frac{\left({ }^{34} \mathrm{~S} /{ }^{32} \mathrm{~S}\right)_{\text {sample }}}{\left({ }^{34} \mathrm{~S} /{ }^{32} \mathrm{~S}\right)_{\text {std }}}-1\right) \times 1000
$$

where ${ }^{34} \mathrm{~S} /{ }^{32} \mathrm{~S}_{\text {sample }}$ and ${ }^{34} \mathrm{~S} /{ }^{32} \mathrm{~S}_{\text {std }}$ denote the ${ }^{34} \mathrm{~S} /{ }^{32} \mathrm{~S}$ ratios of sample and standard, respectively. The analytical precision including the preprocessing operation is better than $\pm 0.2 \%$.

The ${ }^{210} \mathrm{~Pb}$ in aerosols were analyzed by a $\gamma$ ray spectrometer with a well-type Ge semiconductor detector using $1 / 16$ dried filters ${ }^{16)}$.

On the basis of $\mathrm{Na}^{+}$as the tracer for sea salt component, non-sea salt $\mathrm{SO}_{4}{ }^{2-}\left({ }_{\text {nss }} \mathrm{SO}_{4}{ }^{2-}\right)$ concentration and $\delta^{34} \mathrm{~S}$ of non-sea salt sulfate $\left.{ }_{n \text { nss }} \delta^{34} \mathrm{~S}\right)$ were calculated by the following equations :

$$
\begin{aligned}
& { }_{\mathrm{nss}} \mathrm{SO}_{4}{ }^{2-}={ }_{\mathrm{sam} \mathrm{SO}_{4}{ }^{2-}-} \frac{\mathrm{sea}_{\mathrm{sea} \mathrm{Na}_{4}{ }^{2-}}}{{ }_{\mathrm{sam}} \mathrm{Na}^{+}} \\
& { }_{\mathrm{nss}} \delta^{34} \mathrm{~S}= \\
& \frac{\left[\mathrm{sam} \delta^{34} \mathrm{~S} \times{ }_{\mathrm{samSO}}{ }_{4}{ }^{2-}-{ }_{\mathrm{sea}} \boldsymbol{\delta}^{34} \mathrm{~S} \times\left(\mathrm{samSO}_{4}{ }^{2-}-{ }_{\mathrm{nss}} \mathrm{SO}_{4}{ }^{2-}\right)\right]}{{ }_{\mathrm{nss}} \mathrm{SO}_{4}{ }^{2-}}
\end{aligned}
$$

where ${ }_{\text {sam }} \mathrm{SO}_{4}{ }^{2-}$ and $\mathrm{sam} \mathrm{Na}^{+}$are $\mathrm{SO}_{4}{ }^{2-}$ and $\mathrm{Na}^{+}$ concentrations in each samples, seaSO${ }_{4}{ }^{2-}$ and sea $\mathrm{Na}^{+}$are $\mathrm{SO}_{4}{ }^{2-}$ and $\mathrm{Na}^{+}$concentrations in seawater, and ${ }_{\text {sam }} \delta^{34} \mathrm{~S}$ and ${ }_{\text {sea }} \delta^{34} \mathrm{~S}$ are $\delta^{34} \mathrm{~S}$ values of sample and seawater $(+20.3 \%)$, respectively.

\section{Results and discussion}

Monthly variations of (a) $\mathrm{SO}_{4}{ }^{2-}$ and ${ }_{n s s} \mathrm{SO}_{4}{ }^{2-}$ concentrations, (b) $\delta^{34} \mathrm{~S}$ and ${ }_{\mathrm{nss}} \delta^{34} \mathrm{~S}$, and (c) ${ }^{210} \mathrm{~Pb}$ concentration in aerosols are shown in Fig. 2 (January 1996 - May 1999). Atmospheric concentration of $\mathrm{SO}_{4}{ }^{2-}$ and ${ }_{\mathrm{nss}} \mathrm{SO}_{4}{ }^{2-}$ ranged from 0.99 to 10.32 and from 0.95 to $10.21 \mu \mathrm{g} \mathrm{m}^{-3}$, respectively. They are in good correlation. And $\delta^{34} \mathrm{~S}$ and ${ }_{\text {nss }} \delta^{34} \mathrm{~S}$ ranged from 0.97 to 14.90 and from 0.76 to $13.87 \%$, respectively. Although
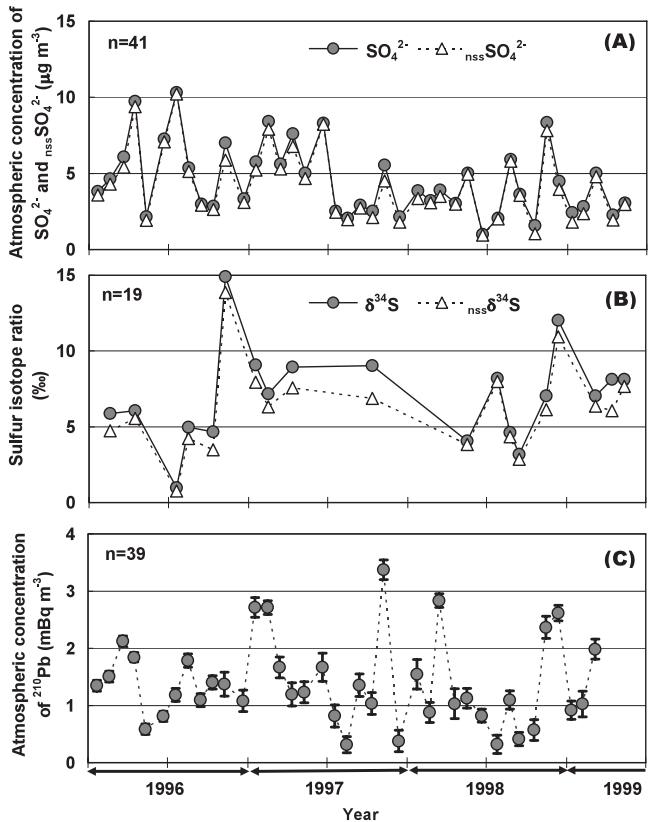

Fig. 2 Variation of (a) atmospheric concentration of $\mathrm{SO}_{4}{ }^{2-}$ and $\mathrm{nss} \mathrm{SO}_{4}{ }^{2-}$, (b) sulfur isotope ratio of sulfate $\left(\delta^{34} \mathrm{~S}\right)$ and non-sea salt sulfate $\left({ }_{\text {nss }} \delta^{34} \mathrm{~S}\right)$ and (c) atmospheric concentration of ${ }^{210} \mathrm{~Pb}$ at Tsuruoka, Japan

$\delta^{34} \mathrm{~S}$ and ${ }_{\text {nss }} \delta^{34} \mathrm{~S}$ were slightly low in summer, clear seasonal variation was not recognized in the atmospheric concentration of $\mathrm{SO}_{4}{ }^{2-}\left({ }_{\text {nss }} \mathrm{SO}_{4}{ }^{2-}\right.$ ) and $\delta^{34} \mathrm{~S}\left({ }_{\mathrm{nss}} \delta^{34} \mathrm{~S}\right)$ because of lack of data. The ${ }^{210} \mathrm{~Pb}$ concentration ranged from 0.3 to 3.4 $\mathrm{mBq} \mathrm{m}^{-3}$ and became low in summer and relatively high in other seasons, showing a seasonal variation.

Figure 3 shows the relationships between atmospheric concentration of ${ }^{210} \mathrm{~Pb}$ and ${ }_{\mathrm{nss}} \mathrm{SO}_{4}{ }^{2-}$. It is a good correlation $(r=0.45, p<0.05)$. It is known that the sulfate aerosols are generated from gaseous sulfur (mainly $\left.\mathrm{SO}_{2}\right)^{17}$. However, Yanagisawa et al. ${ }^{12)}$ reported that $\mathrm{SO}_{2}$ concentration is constant in this area through the year. So, variation of sulfate concentration would mean the presence of the additional sulfate aerosols. In Tsuruoka, north western monsoon 


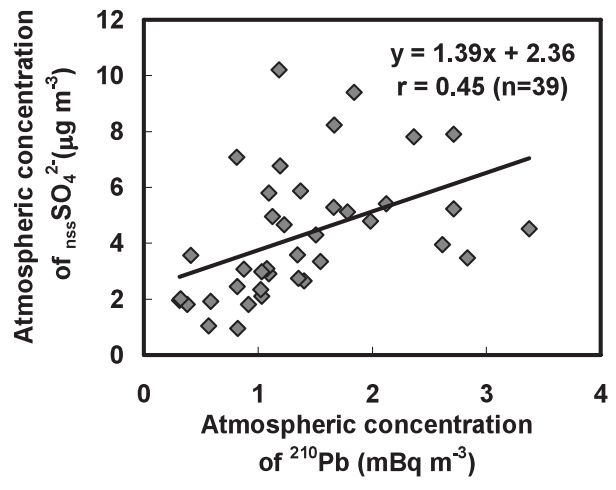

Fig. 3 Relationship between atmospheric concentration of ${ }^{210} \mathrm{~Pb}$ and atmospheric concentration of non-sea salt sulfate at Tsuruoka

is dominant in fall to spring. Therefore, the source of atmospheric ${ }^{210} \mathrm{~Pb}$ and ${ }_{\mathrm{nss}} \mathrm{SO}_{4}{ }^{2-}$ in fall to spring seasons is supposed to be mainly East Asian continent.

Figure 4 shows the relationships between atmospheric ${ }^{210} \mathrm{~Pb}$ concentration and sulfur isotope ratio of non-sea salt sulfate in aerosols at Tsuruoka. It shows a weak positive correlation $(r=0.28)$. It is reported that atmospheric ${ }_{\mathrm{nss}} \mathrm{SO}_{4}{ }^{2-}$ and ${ }^{210} \mathrm{~Pb}$ concentrations are increased by continental air-mass. As the origin of sulfur aerosols, two sources are considered. The one is the continental surface soil particles in arid and semi-arid region including sulfur compounds and the other is secondary aerosols produced by anthropogenic sulfur components. They would be mixed in the atmosphere. Their isotope ratios have wide range values depending on regions. Ito et al. ${ }^{18)}$ reported that $\delta^{34} \mathrm{~S}$ in sand and loess ranged from -0.66 to $+29.50 \%$ (Ave. \pm S.D. : $+11.63 \pm 6.70 \%$ ), and $\delta^{34}$ S values were high in Loess Plateau area and low in Taklimakan Desert area. In addition, Motoyama et al. ${ }^{19)}$ summarized that $\delta^{34} \mathrm{~S}$ values in coals in East Asian area ranged from -27.3 to $+28.9 \%$ with a mean value of $+4.2 \pm 9.6 \%$, and

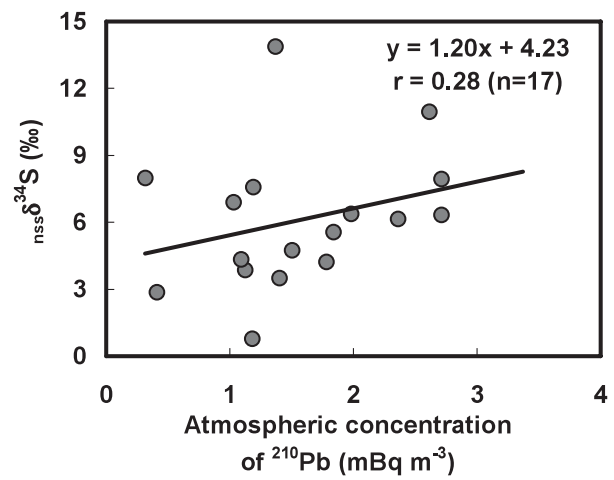

Fig. 4 Relationship between atmospheric concentration of ${ }^{210} \mathrm{~Pb}$ and sulfur isotope ratio of non-sea salt sulfate in aerosols at Tsuruoka

those values in northern China (north of $40^{\circ} \mathrm{N}$ ) were higher than southern China (south of $40^{\circ} \mathrm{N}$ ). Two high data of sulfur isotope ratio in Fig. 4 were observed in November and December. These results indicate that the ${ }_{n s s} \mathrm{SO}_{4}{ }^{2-}$ in aerosols in fall to spring were mainly derived from source regions including high $\delta^{34} \mathrm{~S}$ source such as fossil fuel combustion in north of China and desert sand (loess). Therefore, it seems that the atmospheric aerosols in Tsuruoka were mainly transported from the northern China when ${ }^{210} \mathrm{~Pb}$ concentration and ${ }_{n \text { ss }} \delta^{34} \mathrm{~S}$ showed high values in the same period. Especially, high sulfur isotope ratio suggests much contribution of anthropogenic origin. It is concluded that multi-isotope method using ${ }^{210} \mathrm{~Pb}$ and $\delta^{34} \mathrm{~S}$ is a useful index for evaluating the source of longrange transported aerosols.

\section{Conclusions}

We studied on the validity of combination of ${ }^{210} \mathrm{~Pb}$ concentration and ${ }_{n s s} \delta^{34} \mathrm{~S}$ in aerosols as an index of long-range transported aerosols. As a result, it was suggested that multi-isotope method using $\delta^{34} \mathrm{~S}$ and ${ }^{210} \mathrm{~Pb}$ was useful. As mentioned before, previous studies have re- 

in aerosols as an index of long-range transported aerosols

ported the validity of $\mathrm{Sr}-\mathrm{Nd}$ isotopes, stable $\mathrm{Pb}$ isotopes and ${ }^{137} \mathrm{Cs} /{ }^{90} \mathrm{Sr}$ ratio as tracers of aerosols. The multi-isotope method combined with many other isotopes will be necessary for evaluating exact source region of transported aerosols in future study.

\section{Acknowledgement}

We gratefully acknowledge S. Tanaka, R. Motoyama and K. Onodera (Yamagata University) for their help in sample analysis.

\section{References}

1) IPCC, Cambridge University Press, Cambridge, UK and New York, NY, USA. (2001)

2) Ozeki, T., Ihara, T., Okada, T., Kikuchi, R. and Ogawa, N., Bunseki Kagaku, 53, 1427-1434(2004) (in Japanese with English abstract)

3) Mukai, H., Ambe, Y., Muku, K., Takeshita, K., Fukuma, T., Takahashi, J. and Mizota, S., Atmos. Environ., 24A, 1379-1390 (1990)

4) Sekine, Y. and Hashimoto, Y., J. Jpn. Soc. Air Pollut., 26, 216-226 (1991) (in Japanese with English abstract)

5) Hioki, T., Nakanishi, S., Mukai, H. and Murano, K., J. Aerosol Res., 21, 160-175(2005) (in Japanese with English abstract)

6) Kawamura, H., Tawaki, S., Matsuoka, N., Nagano, T., Momoshima, N., Osaki, S. and Maeda, Y., Chikyukagaku (Geochemistry), 36, 23-33(2002) (in Japanese with English abstract)

7) Nakano, T., Nishikawa, M., Mori, I., Shin, K.,
Hosono, T. and Yokoo, Y., Atmos. Environ., 39, 5568-5575 (2005)

8) Akata, N., Hasegawa, H., Kawabata, H., Chikuchi, Y., Sato, T., Ohtsuka, Y., Kondo, K. and Hisamatsu, S., J. Environ. Radioact., 95, 1-9 (2007)

9) Doi, T., Sato, S. and Sato, J., RADIOISOTOPES, 56, 115-130 (2007)

10) Tsunogai, S., Kurata, T., Suzuki, T. and Yokota, K., J. Atmos. Chem., 7, 389-407 (1988)

11) Satake, H. and Yamane, T., Geochem. J., 26, 299305 (1992)

12) Yanagisawa, F., Tanaka, S. and Kotani, T., $J$. Ecotech. Res., 6, 31-38(2000) (in Japanese with English abstract)

13) Motoyama, R., Yanagisawa, F., Kotani, T., Kawabata, A. and Ueda, A., Seppyo, 62, 215-224(2000) (in Japanese with English abstract)

14) Kanai, Y. and Yanagisawa, F., J. Arid Land Studies, 11, 301-306 (2002)

15) Yanagisawa, F. and Sakai, H., Anal. Chem., 55, 985987 (1983)

16) Kanai, Y., RADIOISOTOPES, 42, 169-172 (1993) (in Japanese with English abstract)

17) Kasahara, M., Earozoru Kenkyu, 11, 120-126 (1996) (in Japanese)

18) Ito, H., Yanagisawa, F., Motoyama, R., Yabuki, S., Kanai, Y. and Akata, N., RADIOISOTOPES, 59, 387-394(2010) (in Japanese with English abstract)

19) Motoyama, R., Yanagisawa, F., Ueda, A., Suzuki, Y., Kanai, Y., Ohsawa, E., Kojima, T. and Akata, N., RADIOISOTOPES, 60, 27-33(2011) (in Japanese with English abstract) 


\section{硫黄同位体比と ${ }^{210} \mathrm{~Pb}$ 濃度を用いた大陸起源エアロゾルの検討}

小谷 卓 $* * *$, 柳澤文孝 $* *$, 金井 豊 $* * * *$, 宮岡明子 $* * * * *$ ，赤田尚史

*鶴岡工業高等専門学校 997-0842 山形県鶴岡市井岡字沢田 104

**山形大学大学院理工学研究科 $* * *$ 山形大学理学部 990-8560 山形県山形市小白川 1-4-12 $* * * *$ 独立行政法人 産業技術総合研究所地質調查総合センター 305-8567 茨城県つくば市東 1-1-1 中央第 7 *****三菱マテリアルテクノ株式会社 330-0835 埼玉県さいたま市大宮区北袋 1-297 $* * * * *$ 財団法人 環境科学技術研究所

039-3212 青森県六ヶ所村尾駮字家ノ前 1-7

大気エアロゾルの供給源を明らかにする手法の一つとして, 大陸起源エアロゾルの指標として利 用されてきた大気中 ${ }^{210} \mathrm{~Pb}$ 濃度と非海塩性硫酸イオンの硫黄同位体比 $\left(\mathrm{nss}^{3} \delta^{34} \mathrm{~S}\right)$ を組み合わせて利 用することを試みた。その結果, 両者には正の相関が涊められ, 両者を組み合わせた方が, より大 陸起源エアロゾルの指標として有効であった。 